\title{
Spindle Cell Oncocytoma of the Adenohypophysis: A Case with Atypical Histomorphological Features and Early Recurrence
}

\author{
Nilüfer Onak Kandemir, Banu Doğan Gün, ${ }^{2}$ Burak Bahadır, \\ Şanser Gül, ${ }^{3}$ Ilker Öz, ${ }^{4}$ Nagehan Özdemir Barışık ${ }^{5}$
}

\author{
'Department of Pathology, Ankara \\ Atatürk Training and Research \\ Hospital, Ankara, Turkey \\ ${ }^{2}$ Department of Pathology, \\ Bülent Ecevit University, Faculty of \\ Medicine, Zonguldak, Turkey \\ ${ }^{3}$ Department of Neurosurgery, \\ Bülent Ecevit University Faculty of \\ Medicine, Zonguldak, Turkey \\ ${ }^{4}$ Department of Radiology, \\ Bülent Ecevit University Faculty of \\ Medicine, Zonguldak, Turkey \\ ${ }^{5}$ Department of Pathology, \\ Health Sciences University Faculty \\ of Medicine, İstanbul, Turkey \\ Submitted: 17.10.2017 \\ Accepted: 19.02.2018 \\ Correspondence: \\ Nilüfer Onak Kandemir \\ Ankara Atatürk Eğitim ve Araştırma \\ Hastanesi Tıbbi Patoloji Bölümü, \\ Ankara, Turkey \\ E-mail: niluferkandemir@yahoo.com
}

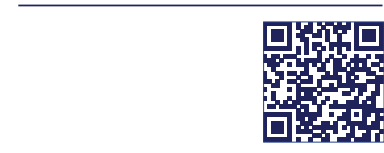

Keywords: Adenohypophysis; sellar tumor; spindle cell oncocytoma.

\begin{abstract}
Spindle cell oncocytoma (SCO) of the adenohypophysis is an extremely rare sellar-region tumor that creates clinicopathologically relevant problems in the differential diagnosis and difficulties in patient management due to the limited data available regarding its biological behavior. A sellar/suprasellar mass was detected and surgery was performed in a $6 \mathrm{I}$-year-old male admitted for impaired vision. The patient was re-operated on twice due to persistence of symptoms and an increase in tumor size at the third and sixth postoperative month. The histopathological examination revealed tumor cells with oncocytic cytoplasm and spindleepithelioid morphology fascicles/layers/pseudoacinar structures. Neoplastic cells showed a positive immunoreactivity with vimentin, epithelial membrane antigen, galectin 3 , thyroid transcription factor-I, and anti-mitochondrial antibodies, and a negative immunoreactivity with epithelial markers, pituitary hormones, and neuroendocrine markers. Compared with the first biopsy sample, the material obtained from recurrent lesions was histologically characterized by increased pleomorphism, atypia, and mitotic activity. Although SCO is defined as Grade I according to the current World Health Organization classification, the considerable risk of early recurrence should be taken into account, especially in cases with atypiapleomorphism and increased mytotic activity.
\end{abstract}

\section{INTRODUCTION}

Spindle cell oncocytoma (SCO) of the anterior pituitary is an extremely rare pituitary tumor. First defined by Roncaroli et al., ${ }^{[1]}$ this tumor was recognized by the World Health Organization (WHO) 2007 classification as a separate entity from other tumors of sellar origin. ${ }^{[2]}$ To date, approximately
26 cases have been reported, with the largest series involving 5 cases. ${ }^{[3-27]}$ This tumor was first regarded as WHO Grade I, since the initial cases exhibited a benign morphology with no recurrence. ${ }^{[2]}$ Recently, however, cases with local recurrence and atypical morphology have been reported..$^{[5,9]}$ 
In this study, the clinical and histopathological properties an SCO case with local recurrences and atypical morphology are discussed and a review of the relevant literature is provided.

\section{CASE REPORT}

Clinical and radiological findings: $A$ 6I-year-old man presented at the center with visual impairment that had begun 3 months earlier and progressed thereafter. An ophthalmological examination revealed bitemporal hemianopsia. A magnetic resonance imaging (MRI) examination showed a mass lesion $35 \times 23 \times 19 \mathrm{~mm}$ in size and internal cystic formations appearing isointense to gray matter on TIA and hyperintense to gray matter on T2A that filled the sellar/suprasellar region and compressed the optic chiasma inferiorly (Figs. I-3). The hormone levels and other biochemical markers were within the normal limits. Based on the clinical and radiological findings, the patient was operated on for an initially diagnosed non-functional pituitary macroadenoma. The intraoperative examination revealed grayish-purple tumor tissue with a rich vascular supply invading the sellar floor and adjacent structures. The patient had persistent symptoms at the third and sixth month postoperatively, and was found to have an increased residual tumor size. A reoperation was performed. At the time of writing, 8 months after the third operation, he is now under close follow-up and no clinical/radiological recurrence has been observed.

Pathological examination: Examination of the hematoxylin and eosin sections of all of the operative material showed tumoral lesions consisting of cells with an oncocytic appearance and spindle/epithelioid/polygonal morphology. The tumor cells had large, eosinophilic, granular cytoplasms, oval-round nuclei, and ill-defined solitary eosinophilic nucleoli. While the epitheloid/polygonal cells formed layers/pseudoacinar structures, the spindle tumor cells formed fascicular/storiform strings. Old and recent foci of bleeding were observed in the tumor tissue, which was rich in thin-walled vasculature. While there was no atypia in the first resection material, the material obtained from recurrent lesions exhibited moderate-severe pleomorphism. Mitotic activity was $0-1 / 10$ high power fields (HPF) in the first resection material, 2-5/10 HPF in the second, and 5-6/10 HPF in the third. No atypical mitosis was observed. Dispersed aggregates of histiocytes with foamy cytoplasms and foci of focal mononuclear inflammation were present. No tissue of normal pituitary origin was visualized in any of the resection material. Staining with reticulin revealed solid islets and pseudoacinar structures surrounding cell groups with a Zellballen-like pattern (Fig. 4).

Immnuohistochemical findings: The tumor cells manifested diffuse vimentin (cytoplasmic), epithelial

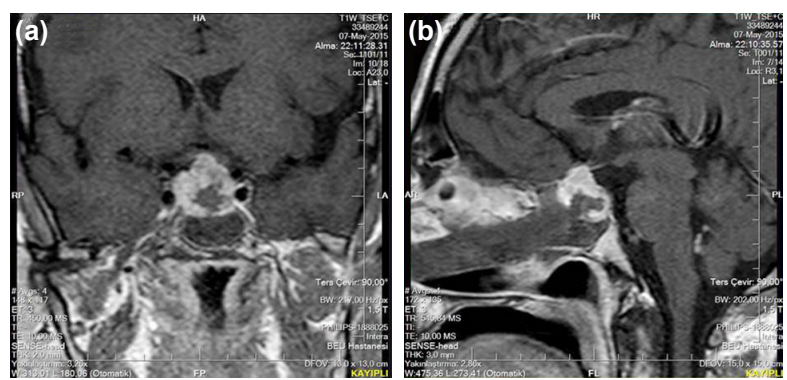

Figure 1. Surgical alterations secondary to intrasellar decompression as well as the tumor's suprasellar and peripheral parts seen on the second day after transsfenoidal surgery. (a) Coronal T1 C+ magnetic resonance imaging (MRI). (b) Sagittal T1 C+ MRI.

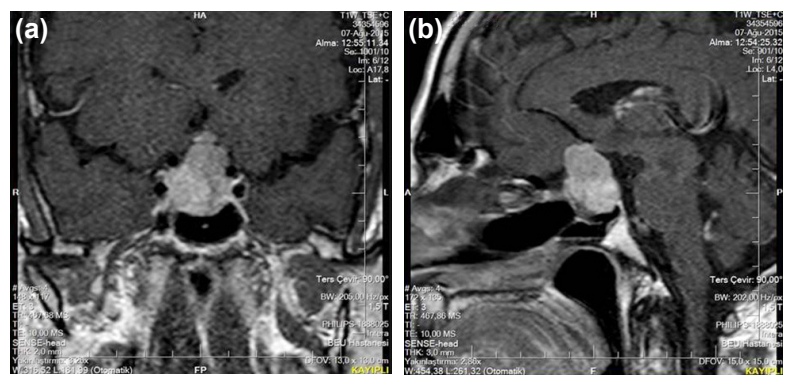

Figure 2. Lesion progression is seen at the third-month control biopsy. The suprasellar extension of the tumor was compressing the optic chiasm. The tumor invadeded the cavernous sinus on the right side and filled the infrasellar space. (a) Coronal T1 C+ magnetic resonance imaging (MRI). (b) Sagittal T1 C+ MRI.

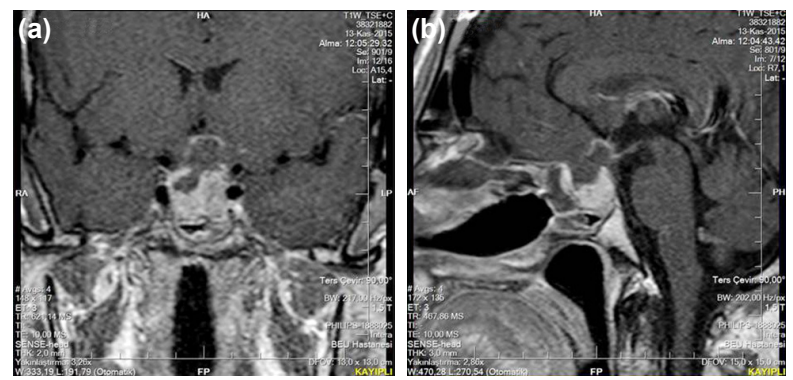

Figure 3. The tumor's suprasellar part has been evacuated and the optic chiasm compression eliminated at the 3-month control, after a pterional craniotomy. (a) Coronal T1 C+ magnetic resonance imaging (MRI). (b) Sagittal T1 C+ MRI.

membrane antigen (EMA) (cytoplasmic, focal membranous), galectin 3 (cytoplasmic), thyroid transcription factor-I (TTF-I) (nuclear), and anti-mitochondrial antibody (AMA) (cytoplasmic-granular) immunoreactivity. A few cell groups demonstrated a reaction with $\mathrm{SI00}$ protein, glial fibrillary acidic protein (GFAP), and synaptophysin. No reaction was evident with epithelial markers other than EMA, hypophyseal hormones, thyroglobulin, chromogranin, smooth muscle actin, and CD34. Based on the histopathological findings, the case was diagnosed as spindle cell oncocytoma (Fig. 5). 

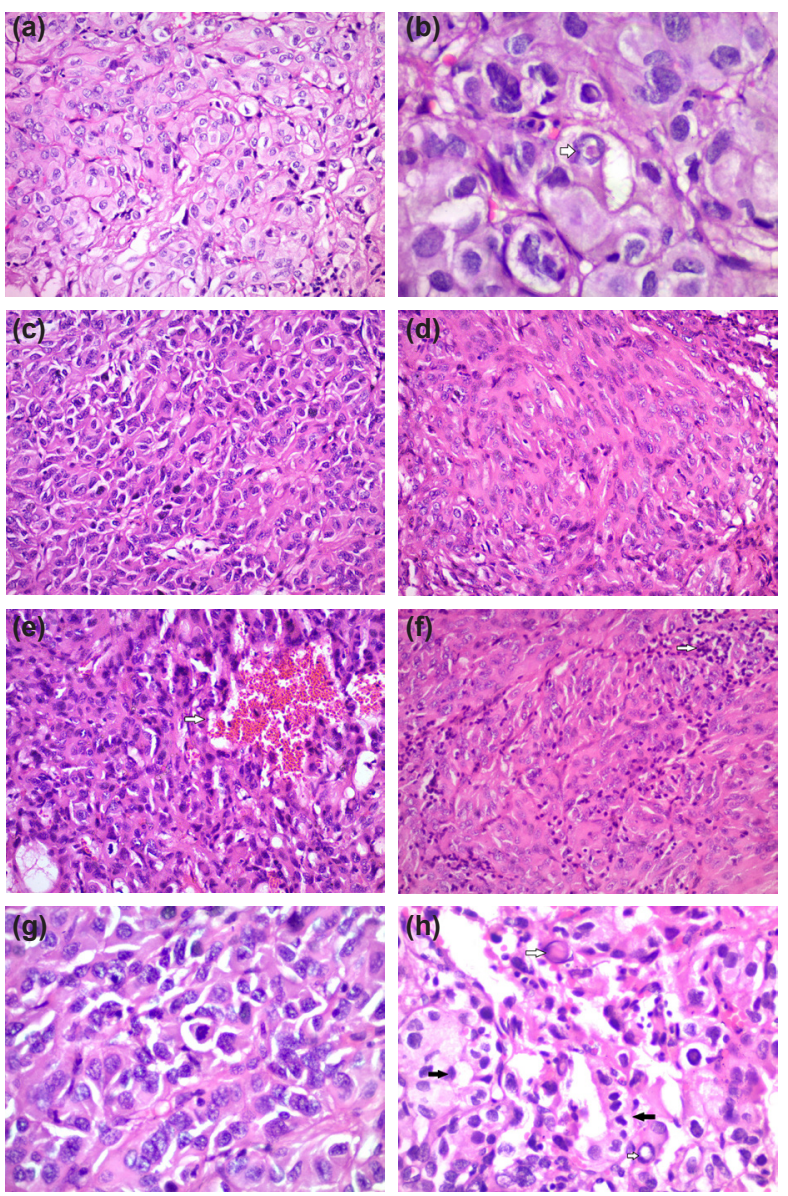

Figure 4. $(\mathbf{a}, \mathbf{b})$ Eosinophilic nucleoli (white arrow) are seen in tumor cells with epitheloid morphology (first resection material: H\&E; Ax100, Bx630). (c) Polygonal cells and (d) spindle cells forming bundles are seen (recurrent lesion: H\&E; C-Dx200). (e) Intratumoral hemorrhage, (f) lymphocytes, nuclear pleomorphism, and $\mathbf{( g )}$ increased mitotic activity (white arrow) are evident in tumor cells in the third surgery (H\&E; Ex400, Fx200, Gx630). (h) In recurrent lesions, nuclear pseudo inclusions (white arrow) and acinus-like (black arrow) structures are seen (H\&E; Hx6300).

\section{DISCUSSION}

SCO is an extremely rare tumor with a prevalence of $0.1 \%$ to $0.4 \%$ among all sellar tumors. ${ }^{[2]}$ According to the gender and age distribution characteristics of previously reported cases, the female/male ratio is $14 / 13$ and the mean age at presentation is 56.4 years (range: $24-76$ years). Approximately $60 \%$ of SCO cases present with impaired vision, while $50 \%$ manifest with panhypopituitarism, and $30 \%$ with headache. A majority of SCO cases receive a preoperative diagnosis of nonfunctional pituitary adenoma, and some cases are confused with other sellar tumors, such as schwannoma or craniopharyngioma. ${ }^{[2,7,23]}$ Table I summarizes the SCO cases reported in the literature. The case reported here is that of a 61 -year-old man whose disease manifested with bitemporal hemianopsia, which is the
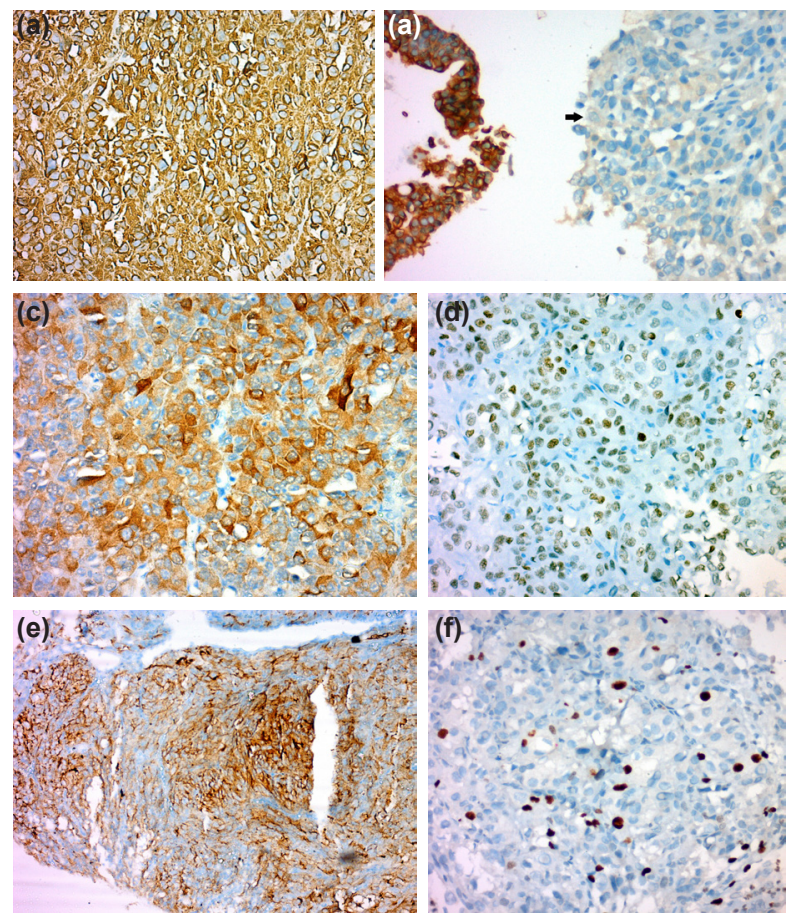

Figure 5. (a) Vimentin, (b) pancytokeratin, (c) anti-mitochondrial antibody, (d) thyroid transcription factor-1, (e) epithelial membrane antigen, and (f) Ki-67 immunopositivity suggestive of SCO diagnosis are seen in tumor tissue (a-f: BSA-DAB, Ax400, Bx100, Cx400,Dx200, Ex100, Fx200).

most common presenting symptom of SCO. The patient underwent surgery with an initial diagnosis of a pituitary macroadenoma.

In a meta-analysis performed by Covington et al., ${ }^{[7]}$ all of the reported SCO cases were mass lesions of pituitary origin that showed intra- and suprasellar localization and invasion of the adjacent adenohypophysis. ${ }^{[7]}$ In our case, the tumor filled the sellar region and extended to the suprasellar region. It had invaded the optic chiasma, left optic nerve, and both cavernous sinuses. Our findings suggest that an ill-bordered separation of the SCO lesion from the adjacent structures complicated its total resection and increased the risk of a residual/recurrent tumor. SCO is rich in cells and vasculature, but the tumor is usually accompanied by areas of acellular regression. This property gives the tumor a unique radiological appearance. Hasiloglu et al. ${ }^{\left[{ }^{[2]}\right]}$ advocated that these MRI properties can be used in making the preoperative diagnosis.

SCO tends to form a relatively large mass lesion, with a reported average diameter of $27 \mathrm{~mm}$ (range: 1.8-60 mm). Intraoperatively, it appears as a gelatinous mass that is grayish-cream in color, or in $50 \%$ of cases, as an elastic, purple, vascular mass. SCO has a thin wall and a rich vascular supply; thus, it may cause abundant bleeding that complicates complete resection. ${ }^{[3-28]}$ Our case had a tumor diameter of $35 \mathrm{~mm}$ and a tumor volume slightly above 
Table I. Spindle cell oncocytoma cases reported in the literature

\begin{tabular}{|c|c|c|c|c|c|c|c|}
\hline Ref. no. & Case no. & Localization & Age (Years) & Sex & Treatment & Follow-up & Recurrences \\
\hline Roncaroli & 5 & Sellar+Suprasellar & 61.6 (mean) & $M: F(3: 2)$ & TS-GTR & $35(2-68) \mathrm{m}$ & - \\
\hline Kloub O & 2 & Sellar+Suprasellar & 73.5 (mean) & $M: F(I: I)$ & STD, TS+R & 10,11 yrs & 3 yrs, 3 yrs- 10 yrs \\
\hline Dahiya & 2 & Sellar+Suprasellar & 26 & $M$ & STR-RT & $6 \mathrm{~m}, 7 \mathrm{yrs}$ & - \\
\hline Vajtai & I & Sellar & 48 & $\mathrm{~F}$ & TS-GTR & $16 \mathrm{yrs}$ & - \\
\hline Farooq & 1 & Sellar & 76 & M & TS-PR+R & $24 \mathrm{~m}$ & - \\
\hline Borota & 1 & Sellar+Suprasellar & 55 & $\mathrm{~F}$ & TS-PR+RT & $30 \mathrm{~m}$ & Slow regrowth \\
\hline Coiré & I & Sellar+Suprasellar & 63 & $\mathrm{~F}$ & $\mathrm{TS}+\mathrm{RT}$ & $5 \mathrm{~m}$ & $5 \mathrm{~m}$ \\
\hline Demssie & I & Sellar+Suprasellar & 59 & $M$ & TS-GTR & $9 \mathrm{~m}$ & $9 \mathrm{~m}$ \\
\hline Matyja & 2 & Sellar, (2) & 64 & $2 \mathrm{~F}$ & TS-GTR, K-GTR & $28 \mathrm{~m}-5 \mathrm{yrs}$ &,- 3 yrs \\
\hline Mlika & I & Sellar+Suprasellar & 45 & $\mathrm{~F}$ & TS-GTR & $3 \mathrm{~m}$ & - \\
\hline Ogiwara & I & Suprasellar & 39 & M & TS-PR, RT & $13 \mathrm{~m}$ & $9 \mathrm{~m}, 13 \mathrm{~m}$ \\
\hline Borges & I & Sellar+Suprasellar & 70 & $\mathrm{~F}$ & TS-GTR & 13 yrs & $13 \mathrm{yrs}$ \\
\hline Vajtai & I & Sellar+Suprasellar & 55 & $\mathrm{~F}$ & TS & NA & NA \\
\hline Romero & I & Sellar & 42 & $\mathrm{~F}$ & TS-GTR & NA & NA \\
\hline Fujisawa & I & Sellar+Suprasellar & 68 & M & TS-PR, RT & $18 \mathrm{~m}$ & $18 \mathrm{~m}$ \\
\hline Singh & I & Sellar+Suprasellar & 68 & M & TS-PR & Ex & - \\
\hline Alexandrescu & 1 & Sellar & 24 & $\mathrm{~F}$ & GTR & $6 \mathrm{~m}$ & - \\
\hline Mete & 7 & NA & NA & NA & NA & NA & NA \\
\hline Rotman & I & Sellar+Suprasellar & 80 & M & TS+GTR & NA & NA \\
\hline $\mathrm{Mu}$ & 2 & Suprasellar & 48.5 (mean) & $2 \mathrm{~F}$ & K-GTR & $15-21 \mathrm{~m}$ & - \\
\hline Voung & 1 & Sellar+Suprasellar & 70 & M & TS-PR & NA & NA \\
\hline Hasiloglu & 3 & Sellar+Suprasellar & $51.6(40-60)$ & $3 M$ & TS-STR & $6-36 \mathrm{~m}$ &,,$-- 12 \mathrm{~m}$ \\
\hline Zygourakis & I & Sellar+Suprasellar & 31 & $\mathrm{~F}$ & TS-STR & $6 \mathrm{~m}$ & - \\
\hline
\end{tabular}

F: Female; GTR: Gross total resection; K: Craniotomy of a MIB-I LI recurrent tumor; M: Male; MIB-I LI: MIB-I labeling index; Mo: Months; NA: Not available; Nu pleo: Nuclear pleomorphism; PR: Partial resection; RT: Radiotherapy; STD: Subtotal debulking; STR: Subtotal resection; TS: Transsphenoidal; Yrs: Years.

the reported average. In our case, a purple, vascular tumor mass was visualized intraoperatively, though no excessive hemorrhage took place.

$\mathrm{SCO}$ is composed of spindle cells forming fascicles and oncocytic epitheloid/polygonal cells forming layers/pseudoacinar structures. Cellular components usually appear monophasic, although some cases may have a striking biphasic appearance. The vascular stroma surrounding epitheloid/polygonal cell groups may form a Zellballen-like pattern with reticulin stain. Roncaroli et al. reported that this tumor may contain interstitial lymphocytic infiltration, hemosiderin laden macrophages, and areas of intratumoral hemorrhage. ${ }^{[21]}$ Necrosis, however, is quite rare. A normal pituitary gland may rarely be located adjacent to the tumor. Vajtai ${ }^{[23,24]}$ and Yoshimoto ${ }^{[26]}$ reported that SCO may contain follicle-like/rosette-like/ependymal areas of differentiation. In our case, the first resected material predominantly contained a spindle cell component, while the samples taken from recurrent lesions predominantly had epitheloid/polygonal cells, which notably form acinus-like organoid strings. The possibility that SCO contains areas of varying levels of differentiation may create difficulty for the pathology diagnosis; however, illustrating the typical histomorphological/immunohistochemical properties of the tumor may help in making the diagnosis.

$\mathrm{SCO}$ is thought to have a benign morphology and low proliferative activity. In recurrent cases, however, nuclear pleomorphism, mitotic activity, and the $\mathrm{Ki}-67$ index may markedly increase. According to literature reports, recurrences may occur in lesions with both low and high Ki-67 indices, and lesions with a high $\mathrm{Ki}-67$ index may reportedly have a greater rate of recurrence ${ }^{[4,5,9,13,21,24]}$ In our case, nucleomegaly and nuclear pleomorphism, albeit both focal, were prominent in the re-excision material compared with the initial biopsy sample. Additionally, mitotic activity and the $\mathrm{Ki}-67$ index were markedly increased in the re-excision material. The early recurrence of our lesion may be related to the tumor's atypical morphology. However, studies with a larger number of patients are needed to fully clarify the effect of these properties on prognosis. 
Table 2. The histomorphological properties of lesions included in the differential diagnosis of spindle cell oncocytoma

\begin{tabular}{|c|c|c|c|c|}
\hline Tumor type & $\begin{array}{l}\text { Light microscopicl } \\
\text { immunohistochemical properties }\end{array}$ & $\begin{array}{l}\text { Ultrastructural } \\
\text { properties }\end{array}$ & $\begin{array}{l}\text { WHO } \\
\text { Grade }\end{array}$ & Cellular origin \\
\hline $\begin{array}{l}\text { Spindle cell } \\
\text { oncocytoma }\end{array}$ & $\begin{array}{l}\text { Spindle-epitheloid-ploygonal cells forming fascicles, } \\
\text { Eosinophilic-oncocytic cytoplasm, } \\
\text { Mild-moderate nuclear atypia, focal pleomorphism, } \\
\text { Focal lymphocytic infiltrate and hemosiderin-laden } \\
\text { macrophages, } \\
\text { Rare mitosis (<I/IO HPF), } \\
\text { Vimentin, TTF-I, EMA, S-100, AMA (+) }\end{array}$ & $\begin{array}{l}\text { Increased number of } \\
\text { enlarged mitochondria } \\
\text { forming packes (?), well- } \\
\text { developed desmosomes, } \\
\text { and intermediate type } \\
\text { junctions } \\
\text { No secretory granules }\end{array}$ & I & $\begin{array}{l}\text { Folliculostellate cells of } \\
\text { anterior pituitary gland, } \\
\text { neuronal precursor cells, } \\
\text { pituitocytes? }\end{array}$ \\
\hline $\begin{array}{l}\text { Granular cell } \\
\text { tumor }\end{array}$ & $\begin{array}{l}\text { Tightly packed polygonal cells forming layers and/ } \\
\text { or fascicles, } \\
\text { PAS positive granules within large cytoplasms, } \\
\text { small nuclei, ill-defined necleoli, focal foam cells, } \\
\text { perivascular lymphocytes, rare mitosis, } \\
\text { pleomorphism apart from AGCT } \\
\text { Vimentin, TTF-I, CD68 (KPI),S-I00 (+) }\end{array}$ & $\begin{array}{l}\text { Phagolysosomes } \\
\text { containing electrone- } \\
\text { dense material, } \\
\text { No neurosecretory } \\
\text { granules }\end{array}$ & I & $\begin{array}{l}\text { Glial elements forming } \\
\text { the stalk and the } \\
\text { posterior lobe of the } \\
\text { pituitary gland } \\
\text { (pituicytes) }\end{array}$ \\
\hline Pituicytoma & $\begin{array}{l}\text { Elongated, bipolar spindle cells forming fascicles and } \\
\text { storiform pattern with fibrillar bacground, } \\
\text { Cytoplasmic granulaes and vacuoles absent, PAS (-), } \\
\text { oval-elongated nuclei contain no or minimal atypia, } \\
\text { Mitosis rare, } \\
\text { Perivascular condensation in reticular fibers, } \\
\text { Vimentin, S-100, GFAP (+) }\end{array}$ & $\begin{array}{l}\text { Cytoplasmic } \\
\text { intermediate filaments } \\
\text { and a variable amount } \\
\text { of mitochondria along } \\
\text { with lysosomes and few } \\
\text { short desmosome-like } \\
\text { intermediate junctions }\end{array}$ & I & $\begin{array}{l}\text { Specialized glial cells of } \\
\text { the neurohypophysis } \\
\text { (pituicytes) }\end{array}$ \\
\hline $\begin{array}{l}\text { Oncocytic } \\
\text { variant } \\
\text { of pituitary } \\
\text { adenoma }\end{array}$ & $\begin{array}{l}\text { Mitosis and pleomorphism rare in tumor where } \\
\text { round-polyhedral cells with acidophilic-oncocytic } \\
\text { cytoplasm form papillary-pseudorosette, } \\
\text { Synaptophysin, chromogranin A, LMWK (+) }\end{array}$ & $\begin{array}{l}\text { Smale-sparse secretory } \\
\text { granules, accumulated } \\
\text { mitochondria }\end{array}$ & I & Achidophil cells \\
\hline $\begin{array}{l}\text { Intrasellar } \\
\text { oncocytic } \\
\text { variant of } \\
\text { meningioma }\end{array}$ & $\begin{array}{l}\text { Meningothelial differentiation including whorls and a } \\
\text { syncytial pattern Interdigitations of cell membranes, } \\
\text { spindle cells, } \\
\text { Vimentin, EMA, S-100 (+) }\end{array}$ & $\begin{array}{l}\text { Abundant intermediate } \\
\text { filaments (Vimentin), } \\
\text { desmosomes, junctions }\end{array}$ & I-II & $\begin{array}{l}\text { Meningothelial } \\
\text { (aracnoidal) cells }\end{array}$ \\
\hline Schwannoma & $\begin{array}{l}\text { Verocay bodies, pericellular basal lamina, } \\
\text { Vimentin, S-100, Calretinin, Leu-7 (+) }\end{array}$ & $\begin{array}{l}\text { Cytoplasmic prosesses, } \\
\text { stromal long-spacing } \\
\text { collagen (Luse body) }\end{array}$ & I & Schwann cell \\
\hline $\begin{array}{l}\text { Solitary } \\
\text { fibrous tumor }\end{array}$ & $\begin{array}{l}\text { Variably cellular and patternless distributions of } \\
\text { bland spindle and ovoid cells within prominent } \\
\text { collagenous stroma } \\
\text { Vimentin, CD34, Bcl-2 (+) }\end{array}$ & $\begin{array}{l}\text { Fibroblast-like cells with } \\
\text { well-developed rough } \\
\text { endoplasmic reticulum, } \\
\text { surrounded with } \\
\text { collagen fibers. }\end{array}$ & & $\begin{array}{l}\text { Mesenchymal cells } \\
\text { demonstrating } \\
\text { myofibroblastic/ } \\
\text { fibroblastic differentiation }\end{array}$ \\
\hline
\end{tabular}


The typical immunohistochemical profile of SCO is central for the differential diagnosis. Vimentin, EMA, TTF-I, and AMA immunopositivity is needed to make a positive diagnosis. Although galectin-3 positivity may occur in many cases, some researchers believe that this is artificial. S100 positivity was found in about $88 \%$ of cases reported in the literature, and synaptophysin positivity in $11 \%$. In our case, the typical immunohistochemical profile of SCO was confirmed, and other diagnostic possibilities were ruled out with the help of an extensive immunopanel. Our case had focal GFAP and S-100 immunopositivity, which are not diagnostic for SCO, but have been reported at varying rates in the literature. ${ }^{[2,8,15,19,22-24,26]}$

Although no definitive information exists regarding the biological behavior of SCO, it is usually considered a lowgrade neoplasm that can be treated with surgery. Although total resection of a tumor is the gold standard treatment method, it is generally difficult to achieve that goal, since the tumor may invade normal pituitary gland and adjacent bony/soft tissues, and because it has a rich vascular supply. In most cases, residual/recurrent lesions were detected after the initial operation. Therefore, some researchers recommend close surveillance for early recurrrence. Some studies have reported recurrence despite total resection. [4,5,9, 13,21,24] Our case was characterized by 2 recurrences with rapid radiological growth in the first 6 months.

Clinically, radiologically, and histologically, the differential diagnosis of SCO comprises many neoplastic/non-neoplastic lesions of the sellar region. The most important among these are null cell adenoma, pituitocytoma, and granular cell tumor. Although these are the most important differential diagnoses of SCO, other histological differential diagnoses include other rare tumors of sellar origin, including intra/suprasellar oncocytic variant meningioma, oncocytic pituitary adenoma, craniopharyngioma, chordoma, choroid glioma, schwannoma, solitary fibrous tumor, paraganglioma, and metastatic lesions with oncocytic appearance. Since oncocytic meningioma, in particular, has a similar immunoprofile to SCO, demonstrating the dural connection significantly helps in distinguishing between them. ${ }^{[2,15,23,26]}$ Table 2 illustrates the clinical and pathological features of SCO and other sellar lesions.

In conclusion, SCO is an extremely rare sellar tumor that poses significant diagnostic difficulties. Although the typical immunohistochemical profile of the tumor significantly helps in the differential diagnosis, ultrastructural studies are recommended to make a definitive diagnosis. This tumor further complicates diagnosis by demonstrating follicle/acinus/rosette-like differentiations of varying patterns. Described as a Grade I tumor in the updated WHO classification, this tumor show early recurrence at significant rates; therefore, we believe that it would be prudent to monitor these lesions closely.
Informed Consent

Approval was obtained from the patients.

Peer-review

Internally peer-reviewed.

Authorship Contributions

Surgical and Medical Practices: Ş:G.; Concept: N.O.K, B.D.G, B.B; Design: N.O.K., N.Ö.B; Data collection \&/or processing: I.Ö, N.O.K.; Analysis and/ or interpretation: all authors; Literature search: all authors; Writing: all authors; Critical review: all authors.

Conflict of Interest

None declared.

\section{REFERENCES}

1. Roncaroli F, Scheithauer BW, Cenacchi G, Horvath E, Kovacs K, Lloyd RV, et al. 'Spindle cell oncocytoma' of the adenohypophysis: a tumor of folliculostellate cells? Am J Surg Pathol 2002;26:1048-55.

2. Louis DN, Ohgaki H, Wiestler OD, Cavenee WK. WHO Classification of Tumours of the Central Nervous System. Lyon: IARC Press; 2007. p. 237-47.

3. Alexandrescu S, Brown RE, Tandon N, Bhattacharjee MB. Neuron precursor features of spindle cell oncocytoma of adenohypophysis. Ann Clin Lab Sci 2012;42:123-29.

4. Borges MT, Lillehei KO, Kleinschmidt-DeMasters BK. Spindle cell oncocytoma with late recurrence and unique neuroimaging characteristics due to recurrent subclinical intratumoral bleeding.J Neurooncol 2011;101:145-54. [CrossRef]

5. Borota OC, Scheithauer BW, Fougner SL, Hald JK, Ramm-Pettersen J, Bollerslev J. Spindle cell oncocytoma of the adenohypophysis: report of a case with marked cellular atypia and recurrence despite adjuvant treatment. Clin Neuropathol 2009;28:91-5. [CrossRef]

6. Coiré CI, Horvath E, Smyth HS, Kovacs K. Rapidly recurring folliculostellate cell tumor of the adenohypophysis with the morphology of a spindle cell oncocytoma: case report with electron microscopic studies. Clin Neuropathol 2009;28:303-8. [CrossRef]

7. Covington MF, Chin SS, Osborn AG. Pituicytoma, spindle cell oncocytoma, and granular cell tumor: clarification and meta-analysis of the world literature since 1893. AJNR Am J Neuroradiol 2011;32:206772. [CrossRef]

8. Dahiya S, Sarkar C, Hedley-Whyte ET, Sharma MC, Zervas NT, Sridhar E, et al. Spindle cell oncocytoma of the adenohypophysis: report of two cases. Acta Neuropathol 2005;110:97-9. [CrossRef]

9. Demssie YN, Joseph J, Dawson T, Roberts G, Carpentier J, Howell S. Recurrent spindle cell oncocytoma of the pituitary, a case report and review of literature. Pituitary 2011;14:367-70. [CrossRef]

10. Farooq MU, Bhatt A, Chang HT. Teaching neuroimage: spindle cell oncocytoma of the pituitary gland. Neurology 2008;71:e3. [CrossRef]

11. Fujisawa H, Tohma Y, Muramatsu N, Kida S, Kaizaki Y, Tamamura $\mathrm{H}$. Spindle cell oncocytoma of the adenohypophysis with marked hypervascularity. Case report. Neurol Med Chir 2012;52:594-8.

12. Hasiloglu ZI, Ure E, Comunoglu N, Tanriover N, Oz B, Gazioglu N, et al. New radiological clues in the diagnosis of spindle cell oncocytoma of the adenohypophysis. Clin Radiol 2016;71:937.e5-937.e11.

13. Kloub O, Perry A, Tu PH, Lipper M, Lopes M. Spindle cell onco- 
cytoma of the adenohypophysis: report of two recurrent cases. Am J Surg Pathol 2002;29:247-53. [CrossRef]

14. Matyja E, Maksymowicz M, Grajkowska W, Olszewski W, Zielinski G, Bonicki W. Spindle cell oncocytoma of the adenohypophysis - a clinicopathological and ultrastructural study of two cases. Folia Neuropathol 2010;48:175-84.

15. Mete O, Lopes MB, Asa SL. Spindle cell oncocytomas and granular cell tumors of the pituitary are variants of pituicytoma. Am J Surg Pathol 2013;37:1694-9. [CrossRef]

16. Mlika M, Azouz H, Chelly I, Said IB, Jemel H, Haouet S, et al. Spindle cell oncocytoma of the adenohypophysis in a woman: a case report and review of the literature.J Med Case Rep 2011;5:64. [CrossRef]

17. $\mathrm{Mu} \mathrm{Q}, \mathrm{Yu}$ J, Qu L, Hu X, Gao H, Liu P, et al. Spindle cell oncocytoma of the adenohypophysis: two case reports and a review of the literature. Med Rep 2015;12:871-6. [CrossRef]

18. Ogiwara H, Dubner S, Shafizadeh S, Raizer J, Chandler JP. Spindle cell oncocytoma of the pituitary and pituicytoma: Two tumors mimicking pituitary adenoma. Surg Neurol Int 2011;2:116. [CrossRef]

19. Romero-Rojas AE, Melo-Uribe MA, Barajas-Solano PA, ChinchillaOlaya SI, Escobar LI, Hernandez-Walteros DM. Spindle cell oncocytoma of the adenohypophysis. Brain Tumor Pathol 2011;28:359-64.

20. Rotman JA, Kucharczyk W, Zadeh G, Kiehl TR, Al-Ahmadi H. Spindle cell oncocytoma of the adenohypophysis: a case report illustrating its natural history with 8-year observation and a review of the literature. Clin Imaging 2014;38:499-504. [CrossRef]
21. Singh G, Agarwal S, Sharma MC, Suri V, Sarkar C, Garg A, et al. Spindle cell oncocytoma of the adenohypophysis: report of a rare case and review of literature. Clin Neurol Neurosurg 2012;114:267-71.

22. Söylemezoğlu F, Aydın Ç. Sellar lezyonların patolojisi. Türk Nöroşir Derg 2014;24:1-10.

23. Vajtai I, Sahli R, Kappeler A. Spindle cell oncocytoma of the adenohypophysis: report of a case with a 16-year follow-up. Pathol Res Pract 2006;202:745-50. [CrossRef]

24. Vajtai I, Beck J, Kappeler A, Hewer E. Spindle cell oncocytoma of the pituitary gland with follicle-like component: organotypic differentiation to support its origin from folliculo-stellate cells. Acta Neuropathol 2011;122:253-8. [CrossRef]

25. Vuong HG, Kondo T, Tran TM, Oishi N, Nakazawa T, Mochizuki $\mathrm{K}$, et al. Spindle cell oncocytoma of adenohypophysis: Report of a case and immunohistochemical review of literature. Pathol Res Pract 2016;212:222-5. [CrossRef]

26. Yoshimoto T, Takahashi-Fujigasaki J, Inoshita N, Fukuhara N, Nishioka H,Yamada S. TTF-1-positive oncocytic sellar tumor with follicle formation/ependymal differentiation: non-adenomatous tumor capable of two different interpretations as a pituicytoma or a spindle cell oncocytoma. Brain Tumor Pathol 2015;32:221-7. [CrossRef]

27. Zygourakis CC, Rolston JD, Lee HS, Partow C, Kunwar S, Aghi MK. Pituicytomas and spindle cell oncocytomas: modern case series from the University of California, San Francisco. Pituitary 2015;18:150-8. [CrossRef]

\section{Adenohipofizin İğsi Hücreli Onkositomu: Atipik Histomorfolojik Özellikler ve Erken Nüks Gösteren Bir Olgu}

Adenohipofizin iğsi hücreli onkositomu (SCO), oldukça nadir görülen, klinikopatolojik açıdan önemli ayırııı tanı zorluklarına neden olan ve biyolojik davranışına yönelik verilerin sınırı olması nedeniyle hasta yönetiminde zorluklar içeren bir sellar bölge tümörüdür. Görme bozukluğu yakınması ile başvuran $6 \mathrm{I}$ yaşındaki erkek hastada, sellar/suprasellar yerleşimli kitle saptandı ve ameliyat edildi. Operasyon sonrası üçüncü ve altıncı ayda hastanın yakınmalarının devam etmesi, tümörün boyutlarında artma olması üzerine iki kez re-operasyon uygulandı. Histopatolojik değerlendirmede iğsi- epitelioid morfolojide, onkositik sitoplazmalı tümör hücrelerinin fasiküller/tabakalar/psödoasiner yapılar oluşturduğu gözlendi. Neoplastik hücrelerde vimentin, EMA, Galektin 3, TTF-I ve AMA ile pozitif, epitelyal belirleyiciler, hipofiz hormonları ve nöroendokrin markırlar ile negatif immünoreaktivite gözlendi. Nükslere ait materyallerde, ilk biyopsi örneğine göre, pleomorfizm, atipi ve mitotik aktivitede artış dikkati çekmiştir. SCO, güncel DSÖ sınıflamasında 'Derece l' olarak tanımlansa da, özellikle atipi-pleomorfizm ve mitotik aktivite sergileyen olgularda önemli oranda erken nüks görülebileceği göz önünde bulundurulmalıdır.

Anahtar Sözcükler: Adenohipofiz; iğsi hücreli onkositom; immünhistokimya; sellar tümör. 